\title{
GMR
}

\section{Genetic expression of pobA and fabHB in Bacillus licheniformis M2-7 in the presence of benzo[a]pyrene}

\author{
Augusto Rojas-Aparicio ${ }^{1}$, José A. Hernández-Eligio ${ }^{2}$, Jeiry Toribio-Jiménez ${ }^{1}$, Miguel \\ Á. Rodríguez-Barrera ${ }^{1}$, Mildred Castellanos-Escamilla ${ }^{3}$ and Yanet Romero- \\ Ramírez $^{1}$ * \\ ${ }^{1}$ Molecular Microbiology and Environmental Biotechnology Laboratory, \\ Autonomous University of Guerrero, México. Ave Lázaro Cárdenas. Ciudad \\ Universitaria, 39070, Chilpancingo, Mexico \\ ${ }^{2}$ Cellular Engineering and Biocatalysis Laboratory, Biotechnology Institute, National \\ Autonomous University of México. Ave Universidad 2001. Chamilpa. 62210, \\ Cuernavaca, Morelos, México \\ ${ }^{3}$ Biochemistry and Molecular Biology Department, University of Calgary. 2500 \\ University Drive NW, AB T2N 1N4, Calgary, Canada \\ Corresponding author: Yanet Romero Ramírez \\ E-mail: yromero@uagro.mx
}

Genet. Mol. Res. 17 (2): gmr16039916

Received Mar 30, 2018

Accepted May 01, 2018

Published April 27, 2018

DOI: http://dx.doi.org/10.4238/gmr16039916

Copyright $(9) 2018$ The Authors. This is an open-access article distributed under the terms of the Creative Commons Attribution ShareAlike (CC BY-SA) 4.0 License.

ABSTRACT. Bacillus licheniformis M2-7 is a heat-resistant bacterium able to biotransform polycyclic aromatic hydrocarbons. It can transform a wide range of these compounds as naphthalene, phenanthrene, pyrene and benzo[a]pyrene. Benzo[a]pyrene is a polycyclic aromatic hydrocarbon of high molecular weight considered as potentially toxic and carcinogenic for humans. Aiming to discover the genes involved in the biotransformation of benzo[a]pyrene, we made a B. licheniformis M2-7 genomic library in E. coli. We isolated two E. coli strains that were able to grow in minimal salt medium supplemented with benzo[a]pyrene. From the analysis of the DNA fragments in the clones H23 and H38, we identified open reading frames coding for 5 possible genes, among them pobA and fabHB, which products are the enzymes 4hydroxybenzoate 3-monooxygenase and the ketoacyl-ACP synthase 
III, respectively. To evaluate the role of these genes in the metabolism of benzo[a]pyrene in B. licheniformis M2-7, we estimated their relative expression through reverse transcription quantitative PCR. Finally, we observed that the genes pobA and fabHB were overexpressed after $3 \mathrm{~h}$ under induction with benzo[a]pyrene, suggesting that this strain could use these genes during the metabolism of this PAH, plus it does it in a faster time than that reported for other bacterial genera

Key words: 4-hydroxybenzoate 3-monooxygenase (pobA); KetoacylACP synthase III (fabHB); Bacillus licheniformis M2-7; benzo[a]pyrene; Reverse transcription quantitative (PCR)

\section{INTRODUCTION}

Benzo[a]pyrene $(\mathrm{BaP})$ is a polycyclic aromatic hydrocarbon $(\mathrm{PAH})$ of high molecular weight which solubility in water is very low. This produces a limited availability in the environment (Kanaly and Harayama, 2010; Banach-Szott et al., 2015). BaP is considered to be potentially carcinogenic for humans (IARC, 1983; VázquezGómez et al., 2016) because during its biotransformation it is oxidized by the enzyme epoxide hydrolase to benzo[a]pyrene 7,8-diol-9,10-epoxide, a highly toxic compound (Harvey, 1996). Despite its toxicity there are studies indicating the activity of different microorganisms in the removal of $\mathrm{BaP}$ in low concentrations, where bacteria are the main organisms (Kanaly and Harayama, 2000; Moody et al., 2004). In the bacterium Mycobacterium vanbaalenii PYR-1, this organism initially oxidized benzo[a]pyrene with dioxygenases and monooxygenases at C-4,5, C-9,10, and C-11,12. The major intermediates of benzo[a]pyrene metabolism that had accumulated in the culture media after $96 \mathrm{~h}$ of incubation were benzo[a]pyrene cis-4,5-dihydrodiol, benzo[a]pyrene cis-11,12-dihydrodiol, benzo[a]pyrene trans-11,12-dihydrodiol, 10-oxabenzo-[def]chrysen-9one, and hydroxymethoxy and dimethoxy derivatives of benzo[a]pyrene. From this data, a hypothetical transformation pathway was generated where a wide number of enzymes were included (Moody et al., 2004). An interesting example is the bacterium Novosphingobium pentaromativorans US6-1 that metabolizes BaP by using ring hydroxylating dioxygenases to complete the degradation through different pathways until entering the tricarboxylic acid cycle. For $N$. pentaromativorans US6-1 it was reported that the HBMO gene coding for the enzyme 4-hydroxybenzoate 3-monooxygenase gets overexpressed after the incubation with BaP during $12 \mathrm{~h}$ (Lyu et al., 2014). Other studies have been shown that B. licheniformis grows in the presence of BaP, inducing the expression of genes coding for monooxygenases (Sowada et al., 2014). There are several reports about BaP metabolism, however most of them focus on the physical and chemical aspects, reporting the intermediary metabolites that are generated. But little is known about the genetic processes involved in the BaP degradative pathways (Kanaly and Harayama, 2000; Moody et al., 2004; Lyu et al., 2014; Sowada et al., 2014).

B. licheniformis M2-7 is a heat-resistant bacterium, isolated from the surface of hot springs in Guerrero, Mexico. Recent investigations have shown that these bacteria have the ability to grow in crude oil and its derivatives as well as in the presence of different PAHs (naphthalene, phenanthrene, pyrene and BaP) (GuevaraLuna et al., 2018, under review). In addition, our group did an analysis by gas chromatography-mass spectrometry to the extracts of the B. licheniformis M2-7 strain after $3 \mathrm{~h}$ of incubation with BaP. We discovered that the bacterium transforms the $\mathrm{BaP}$ with the catechol 2, 3-dioxygenase (C23O), generating 3 intermediary metabolites, one of them being the phthalic acid. It was suggested that the BaP hypothetical transformation pathway of B. licheniformis M2-7 starts with the enzyme $\mathrm{C} 23 \mathrm{O}$, which incorporates molecular oxygen into the carbons 9 and 10 of the $\mathrm{BaP}$, generating benzo[a]pyrene cis-9,10-dihydrodiol, subsequently metabolized by the meta pathway to phthalic acid (Guevara-Luna et al., 2017, under review). It is for this metabolic versatility that the strain M2-7 has been proposed as a potential candidate for bioremediation of contaminated areas with PAHs. The aim of this work was to identify the genes related to the BaP biotransformation in B. licheniformis M2-7. This was achieved through the generation of a B. licheniformis genomic library in E. coli cells. Finally, we analyzed the expression of the genes pobA and $f a b H B$ (encoding the enzymes 4-hydroxybenzoate 3monooxygenase and the ketoacyl-ACP synthasa III, respectively), in the strain M2-7 induced with BaP. 


\section{MATERIALS AND METHODS \\ Bacterial strains and growth conditions}

Cultures of B. licheniformis M2-7 and E. coli XL1-Blue were grown in LB medium (composition in g/L: casein peptone 10, sodium chloride 10, yeast extract 5 for liquid medium, supplemented with $15 \mathrm{~g}$ of agar for solid medium) at a temperature of $37^{\circ} \mathrm{C}$ for $24 \mathrm{~h}$. The antibiotic used for E. coli was ampicillin $200 \mathrm{mg} / \mathrm{mL}$. The BaP used was from Sigma-Aldrich HPLC purity ( $\geq 96 \%$ ), and the stock solution was prepared with acetone at 1 $\mathrm{mg} / \mathrm{mL}$ concentration. To confirm the metabolic capacity of $E$. coli to grow in $\mathrm{BaP}$ or to measure the genetic expression of $B$. licheniformis M2-7, the strains were grown in minimal salt medium (MSM) developed by Zeinali et al., (2008) with some modifications (composition in $\mathrm{g} / \mathrm{L} \mathrm{NH} \mathrm{NH}_{4} \mathrm{Cl}, 1 ; \mathrm{Na}_{2} \mathrm{HPO}_{4}, 0.380 ; \mathrm{KH}_{2} \mathrm{PO}_{4} \cdot \mathrm{H}_{2} \mathrm{O}$, 0.380; $\mathrm{MgSO}_{4} \cdot 6 \mathrm{H}_{2} \mathrm{O}, 0.080 ; \mathrm{CaCl}_{2}, 0.070 ; \mathrm{KCl}, 0.040 ; \mathrm{FeSO}_{4} .7 \mathrm{H}_{2} \mathrm{O}, 0.001$; and $20 \%$ glucose or $10 \mu \mathrm{g} / \mathrm{mL} \mathrm{BaP}$ as the only carbon source) supplemented with a solution of trace elements $(2.5 \mathrm{~mL}$ per liter of medium, composition in $\mathrm{g} / \mathrm{L} \mathrm{MgCl}_{2} .4 \mathrm{H}_{2} \mathrm{O}, 0.027 ; \mathrm{H}_{3} \mathrm{BO}_{3}, 0.031 ; \mathrm{ZnCl}_{2}, 0.050, \mathrm{CuCl}_{2} .2 \mathrm{H}_{2} \mathrm{O}, 0.01 ; \mathrm{NiCl}_{2} .6 \mathrm{H}_{2} \mathrm{O}, 0.02$; $\mathrm{CoCl}_{2} \cdot 6 \mathrm{H}_{2} \mathrm{O}, 0.036$ and $\left.\mathrm{Na}_{2} \mathrm{MoO}_{4} \cdot 2 \mathrm{H}_{2} \mathrm{O}, 0.03\right)$ and adjusted to $\mathrm{pH} 7$.

\section{Growth analysis of $E$. coli strains $\mathrm{H} 23$ and $\mathrm{H38}$ in the presence of benzoapyrene}

The E. coli strains $\mathrm{H} 23$ and $\mathrm{H} 38$ were cultured in liquid $\mathrm{LB}$ medium at $37^{\circ} \mathrm{C}$ for $16-18 \mathrm{~h}$. The cells were harvested, washed three times with $\mathrm{H}_{2} \mathrm{O}$ and inoculated in $50 \mathrm{~mL}$ of $\mathrm{MSM}$ with $10 \mu \mathrm{g} / \mathrm{mL}$ of $\mathrm{BaP}$, to an $\mathrm{OD}_{600}=0.3$. The cultures were incubated at $37^{\circ} \mathrm{C}$ in the dark and mixed using a rotary shaker at $200 \mathrm{rpm}$. The controls used were as follows: 1) the MSM with the same concentration of BaP with no inoculate; 2) the MSM with the same concentration of $\mathrm{BaP}$ and inoculated with the $E$. coli strain harboring pUC18. The assays were done in duplicate and the growth was measured through the protein concentration by the Bradford method (Bradford, 1976) every 3 days for 16 days

\section{Sequencing of the DNA fragments inserted in pUC18 that conferred the ability to grow in BaP to the $E$. coli strains $\mathrm{H} 23$ and $\mathrm{H} 38$}

A plasmid DNA extraction of the strains H23 and H38 was performed and the inserted fragments from $B$. licheniformis M2-7 were released by digestion with the restriction enzyme HindIII (Thermo Scientific). For the capillary automated sequencing, we used the primer pair m13/pUC-40 Forward 5'-GTT TTC CCA GTC ACG TTG TA-3' y m13/pUC Reverse 5'-TTG TGA GCG GAT AAC AAT TTC-3’. A mix of 10 pmoles of the oligo plus $300 \mathrm{ng}$ of the plasmid in a final volume of $16 \mu \mathrm{L}$ was done. The nucleotide sequences recovered from the strains were analyzes through alignments with the genome of the B. licheniformis strain, DSM13=ATCC 14580.

\section{Reverse transcription and quantitative polymerase chain reaction (RT-qPCR)}

We cultured B. licheniformis M2-7 in MSM with $10 \mu \mathrm{g} / \mathrm{mL}$ of $\mathrm{BaP}$ to a $\mathrm{OD}_{600}=0.5$. The cultures were incubated at $50^{\circ} \mathrm{C}$ for $12 \mathrm{~h}$ in the dark and mixed using a rotary shaker at $200 \mathrm{rpm}$. As control, we used the MSM under the same conditions but without BaP. The samples were done by triplicate. We then extracted and purified the total RNA of B. licheniformis M2-7 according to the protocol developed by Damm et al., (2015) with some modifications. The residual DNA contaminant was degraded with DNasa I (Thermo Scientific). The RNA was storaged at $-70^{\circ} \mathrm{C}$. For the generation of complementary DNA (DNAc) we used the kit RevertAid (Thermo Scientific). The amplification reaction was done as follows: $1 \mu \mathrm{g}$ of total RNA, $20 \mathrm{pmol} / \mu \mathrm{L}$ of primer reverse (Table 1), $2 \mu \mathrm{L}$ of dNTP's $(10 \mathrm{mM}$ ), $4 \mu \mathrm{L}$ of reaction buffer $5 \mathrm{X}, 1 \mu \mathrm{L}$ of Rnase inhibitor (40 $\mathrm{U}$ ) and $0.5 \mu \mathrm{L}$ of reverse transcriptase. The reaction was incubated at $42^{\circ} \mathrm{C}$ for $1 \mathrm{~h}$ and then inactivated at $70^{\circ} \mathrm{C}$ during $10 \mathrm{~min}$. The cDNA was storaged at $-20^{\circ} \mathrm{C}$.

The qPCR was done in a LightCycler® 96 Instrument II from Roche. The PCR reaction was done in a volume of $20 \mu \mathrm{L}$ as follows: $1 \mu \mathrm{L}$ of cDNA, $10 \mu \mathrm{L}$ of Master Mix 2x (LightCycler® 480 SYBR Green I, from Roche) and $2.5 \mathrm{mM}$ of primer (Table 1). Each reaction was done by triplicate. The amplification was performed done as follows: denaturation at $95^{\circ} \mathrm{C}$ during $10 \mathrm{~min}$, followed for 40 cycles at $95^{\circ} \mathrm{C}$ for $10 \mathrm{~s}$ and $60^{\circ} \mathrm{C}$ for $60 \mathrm{~s}$. The analysis of relative expression was done using the method $2^{-\Delta \Delta \mathrm{CT}}$. 
Table 1. Primer used in this study

\begin{tabular}{|c|c|c|c|c|}
\hline Primer & $\begin{array}{l}\text { Gene and target } \\
\text { protein }\end{array}$ & $\begin{array}{l}\text { Seque } \\
5^{\prime}-3^{\prime}\end{array}$ & nce & Amplicon size (bp) \\
\hline HBMo Fw & $\begin{array}{ll}\text { pobA } & (4- \\
\text { hydroxybenzoate } & 3- \\
\text { monooxygenase) }\end{array}$ & $\begin{array}{l}\text { AGA } \\
\text { GCC } \\
\text { CAT } \\
\text { TT }\end{array}$ & $\begin{array}{l}\text { AGC } \\
\text { TGT } \\
\text { CAC }\end{array}$ & 117 \\
\hline HBMo Rev & $\begin{array}{ll}\text { pobA } & (4- \\
\text { hydroxybenzoate } & 3- \\
\text { monooxygenase) }\end{array}$ & $\begin{array}{l}\text { TCC } \\
\text { GGA } \\
\text { CTT } \\
\text { CT }\end{array}$ & $\begin{array}{l}\text { TTC } \\
\text { ATG } \\
\text { TGT }\end{array}$ & 117 \\
\hline KASi Fw & $\begin{array}{l}\text { fabHB (ketoacyl- } \\
\text { ACP synthase III) }\end{array}$ & $\begin{array}{l}\text { ACT } \\
\text { GAT } \\
\text { ACG } \\
\text { TG }\end{array}$ & $\begin{array}{l}\text { TCG } \\
\text { GGA } \\
\text { AAG }\end{array}$ & 105 \\
\hline KASi Rev & $\begin{array}{l}\text { fabHB (ketoacyl- } \\
\text { ACP synthase III) }\end{array}$ & $\begin{array}{l}\text { TAT } \\
\text { GTC } \\
\text { AAG } \\
\text { TG }\end{array}$ & $\begin{array}{l}\text { GCA } \\
\text { CGG } \\
\text { TGA }\end{array}$ & 105 \\
\hline CDox Fw & $\begin{array}{l}\text { catE (catechol 2,3- } \\
\text { dioxygenase) }\end{array}$ & $\begin{array}{l}\text { AGC } \\
\text { GGA } \\
\text { ACG } \\
\text { TG }\end{array}$ & $\begin{array}{l}\text { AGG } \\
\text { ACT } \\
\text { TGA }\end{array}$ & 114 \\
\hline CDox Rev & $\begin{array}{l}\text { catE (catechol 2,3- } \\
\text { dioxygenase) }\end{array}$ & $\begin{array}{l}\text { GGA } \\
\text { GTC } \\
\text { TTT T }\end{array}$ & $\begin{array}{l}\text { CGT } \\
\text { CGA } \\
\text { TG TT }\end{array}$ & 114 \\
\hline rpoB Fw & $\begin{array}{l}r p o B \text { (beta subunit of } \\
\text { the } \\
\text { polymerase) }\end{array}$ & $\begin{array}{l}\text { GGT } \\
\text { ACC } \\
\text { ACT } \\
\text { AT }\end{array}$ & $\begin{array}{l}\text { TTT } \\
\text { GCG } \\
\text { GTC }\end{array}$ & 115 \\
\hline rpoB Rev & $\begin{array}{l}r p o B \text { (beta subunit of } \\
\text { the } \\
\text { polymerase) }\end{array}$ & $\begin{array}{l}\text { GAA } \\
\text { TAA } \\
\text { GCA } \\
\text { TA }\end{array}$ & $\begin{array}{l}\text { CCG } \\
\text { CCG } \\
\text { ACT }\end{array}$ & 115 \\
\hline
\end{tabular}

\section{RESULTS}

Analysis of the growth of $E$. coli strains $\mathrm{H} 23$ and $\mathrm{H38}$ in the presence of benzoapyrene

A total of 1668 E. coli transformant were obtained from $B$. licheniformis library. We carried out a first selection filter by growing them in solid MSM supplemented with BaP (data not shown). We selected two strains, which were incubated in liquid MSM supplemented with BaP for 16 days (Figure 1). Both strains showed an adaptation period to the culture medium conditions during the first 4 days of growth, after that, we observed an increase in the growth rate and it was different for each one. H23 increased its growth rate at day 7 th (3.58 $\mu \mathrm{g} / \mathrm{mL}$ of protein); reaching its maximum growth at day $16(4.38 \mu \mathrm{g} / \mathrm{mL}$ of protein); in contrast to the other strains. The strain H38 showed a constant growth during the 16 days, having a concentration of $3.67 \mu \mathrm{g} / \mathrm{mL}$ of protein in the last measurement. The growth rate of both transformant strains was compared to the growth of the wild type control strain (Figure 1).

The graph shows the growth measured by protein quantification of the strains $\mathrm{H} 23$ and $\mathrm{H} 38$, and the control strain (pUC18). Bacteria were incubated at $37^{\circ} \mathrm{C}$ for 16 days. The experiments were done in duplicate. Standard deviation is shown. 


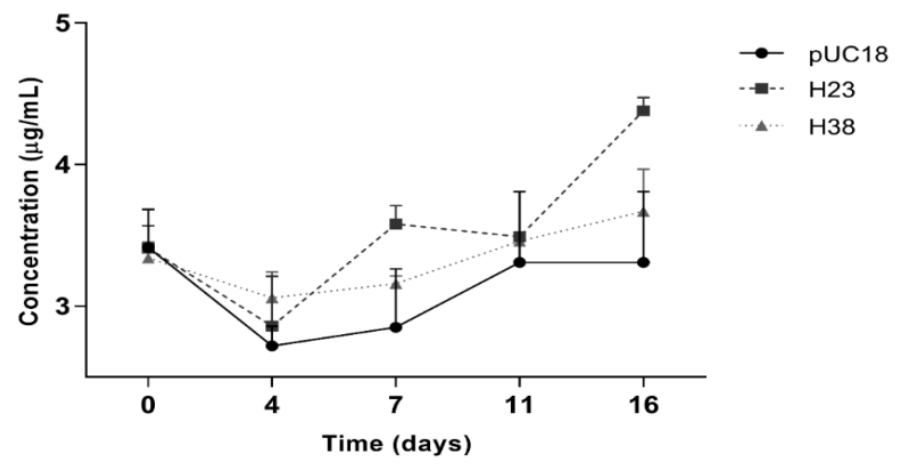

Figure 1. Growth kinetics of $E$. coli strains in the presence of benzoapyrene.

\section{Sequencing analysis of the DNA fragments inserted in pUC18, that conferred the transformants the ability to grow in medium with BaP}

In order to determine the genetic elements that confer the ability to the strains $\mathrm{H} 23$ and $\mathrm{H} 38$ to grow in medium containing $\mathrm{BaP}$, we did a restriction analysis of the purified plasmids to observe the pattern of the inserted fragments. The strain $\mathrm{H} 23$ showed three fragments bigger than $1 \mathrm{~Kb}$ and the strain $\mathrm{H} 38$ one fragment of $1.5 \mathrm{~Kb}$ (Figure S1). This result suggested the presence of at least one gene in the plasmids, which were then sent for sequencing. In this analysis we identified five possible open reading frames (ORF) that code for different proteins (Table 2). This suggests that the acquired ability to grow in $\mathrm{BaP}$ is due to the presence of at least one of these proteins. In the fragment from the strain H23, we identified the genes prpB, TRNA_RS41120 and pobA that encode a membrane transporter type MFS, the enzyme methyl isocitrate lyase and the enzyme 4hydroxybenzoate 3-monooxygenase, respectively. On the other hand, in the fragment from the strain $\mathrm{H} 38$, the genes identified were TRNA_RS26940 and $f a b H B$ that encode for a hypothetical protein and the enzyme ketoacyl-ACP synthase III, respectively.

Table 2. Genes identified from the plasmid DNA sequencing in the E. coli strains.

\begin{tabular}{|c|c|c|c|c|c|c|}
\hline Strain & Gene & Description & Protein & Coverage(\%) & $\begin{array}{l}\text { Identity } \\
(\%)\end{array}$ & $\begin{array}{c}\text { Accession } \\
\text { number }\end{array}$ \\
\hline \multirow[t]{3}{*}{ H23 } & prpB & $\begin{array}{l}\text { Methyl isocitrate } \\
\text { lyase }\end{array}$ & prpB & 99 & 99 & WP_011198423.1 \\
\hline & & Transporter MFS & TRNA_RS41120 & 65 & 99 & WP_009329802.1 \\
\hline & $p o b A$ & $\begin{array}{l}\text { 4- } \\
\text { hydroxybenzoate } \\
3- \\
\text { monooxygenase }\end{array}$ & pobA & 26 & 99 & WP_011198399.1 \\
\hline \multirow[t]{2}{*}{ H38 } & & $\begin{array}{l}\text { Hypothetical } \\
\text { protein }\end{array}$ & TRNA_RS26940 & 94 & 100 & WP_009328937.1 \\
\hline & $\mathrm{fabHB}$ & $\begin{array}{l}\text { Ketoacyl-ACP } \\
\text { synthase III }\end{array}$ & fabHB & 56 & 99 & WP_011197721.1 \\
\hline
\end{tabular}

${ }^{a}$ The similarity level was based on the alignments with BLASTX of non redundant proteins from the NCBI database.

The strain used as reference for the alignments was B. licheniformis DSM13=ATCC 14580. The analysis of the fragments DNA with the biodegradation rates (Figure 1), suggest that during the growth in MSM with BaP, these enzymes promote the development of the strains $\mathrm{H} 23$ and H38. According to different authors, the degradation metabolism of high molecular weight PAHs involves at least 23 different proteins, among them monooxygenases and dioxygenases, that participate in the initial pathway of degradation; and enzymes that participate in the fatty acids metabolism as part of the final pathway of degradation. Interestingly, these two 
strains harbor the genes pobA $(\mathrm{H} 23)$ and $f a b H B(\mathrm{H} 38)$ in their plasmids, encoding for the enzymes 4hydroxybenzoate 3-monooxygenase and the ketoacyl-ACP synthase III, respectively (Table 2). In order to determine if the transcription of the genes pobA and $f a b H B$, is induced by the presence of $\mathrm{BaP}$ in the $B$. licheniformis strain M2-7, we analyzed their expression. In addition, we measured the relative expression of the gen catE that codes for the enzyme C23O (TRNA_RS25790) as a positive control of a gene directly involved in the biotransformation of benzoapyrene, because the activity of this enzyme in B. licheniformis M2-7 was previously observed after $3 \mathrm{~h}$ of incubation with BaP (Guevara-Luna et al., 2017, under review).

\section{Relative expression of genes catE, fabHB, and $p o b A$ in B. licheniformis M2-7}

The degradation pathway of $\mathrm{BaP}$ is complex and in order to understand its metabolism, many microorganisms have been used in trials to analyze if they can use it as a carbon source. Moreover, the genes that participate in the degradation of the $\mathrm{BaP}$ in B. licheniformis M2-7 are not known. For this reason, we determined the relative expression levels of three genes in the genome of B. licheniformis M2-7 under the induction of BaP (Figure 2).
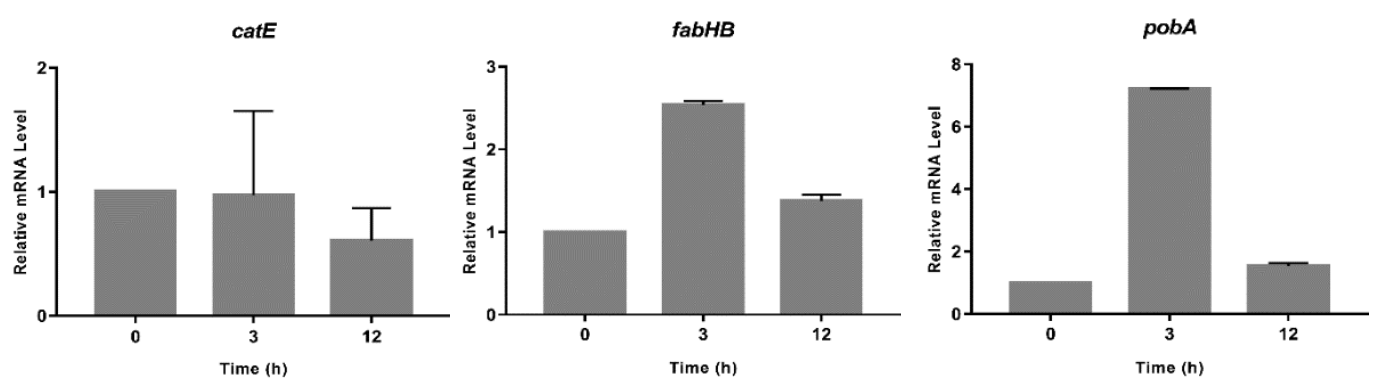

Figure 2. Quantitative PCR.

Relative expression quantification of the genes catE (catechol 2,3-dioxygenasa), fabHB (ketoacyl-ACP synthase III), and pobA (4-hydroxybenzoate 3-monooxygenase) in B. licheniformis M2-7 after induction with BaP.

The expression of the gene catE was basal during the three first hours of exposure (0.97-fold), after $12 \mathrm{~h}$ decreased by 0.6 -fold after induction in $\mathrm{BaP}$. (Figure 2A). In the Figure 2B, there is an overexpression of the gen $f a b H B$ after $3 \mathrm{~h}$ (2.5-fold higher) and $12 \mathrm{~h}$ (1.3-fold higher) of exposure to BaP. In the Figure 2C, we can observe an overexpression of the gene $p o b A$ in the first $3 \mathrm{~h}$ with $\mathrm{BaP}$ (7.2-fold higher), then decreased by 1.5fold after $12 \mathrm{~h}$. These results all together suggest that the overexpression of the genes $p o b A$ and $f a b H B$ after the first $3 \mathrm{~h}$ of exposure to benzo[a]pyrene is driven by their participation in the metabolism of PAH.

\section{DISCUSSION}

A total of 1668 E. coli transformant were exposed to BaP. From those, strains H23 and H38 showed better growth compared to the negative control. Based on this analysis and the sequencing of DNA we were able to relate the ORFs harbored in the $\mathrm{H} 23$ and $\mathrm{H} 38$ plasmids, encoding for different proteins, with the $\mathrm{BaP}$ metabolism.

The strain H23 harbors three enzymes. The first of them is a methyl isocitrate lyase, a protein involved in the metabolism of glycolipids and probably in the production of biosurfactants (Rooney, 1979; Kato and Watanabe, 2009). There are studies reporting the bacterial degradation of alkanes by Alcanivorax borkumensis MM1 and Pseudomonas aeruginosa PG201 using glycolipids to increase the alkane's biodisponibility (Abraham et al., 1998; Holden et al., 2002). The second ORF codes for a membrane transport protein type major facilitator superfamily (MFS), which are proteins that facilitate movement of small solutes across cell membranes in response to chemiosmotic gradients in prokaryote cells. They participate in the detoxification of endogenous and exogenous metabolites (Dean et al., 2001; Biemans-Oldehinkel et al., 2006; Oldham et al., 2008; Kim et al., 2017). This last antecedent suggests that the $\mathrm{BaP}$ can get into the cell causing toxic effects. As an example, there is Euplotes crassus, where it was observed that an $\mathrm{ABC}$ transporter allowed the access of $\mathrm{BaP}$ into the cell 
which then inhibited the activity of the transporter, causing the cellular toxicity of the protozoan (Kim et al., 2017). However, in the strain $\mathrm{H} 23$ we observed that the presence of $\mathrm{BaP}$ did not have any toxic effect and this result is attributed to the last ORF that encodes for a monooxygenase protein. This effect could be due to the 4hydroxybenzoate 3-monooxygenase present in the plasmid DNA from strain H23, incorporates molecular oxygen to the BaP benzene rings and in that way allowing the strain's survival. Finally, we suggest that the strain H23 uses the enzyme methyl isocitrate lyase to make the BaP more bio-available, then the membrane transporter facilitates the intake to the cell and the enzyme 4-hydroxybenzoate 3-monooxygenase metabolizes the PAH.

The strain H38 harbors two enzymes, the first one is a hypothetical protein while the second one is the ketoacylACP synthase III. This protein has been described in Gram-positive bacteria and participates in the fatty acid and polyunsaturated fatty acid biosynthesis (Zaccai et al., 2008; Johnson et al., 2011). As mentioned before it is known that the metabolism of high molecular weight PAHs, specifically that of the BaP, involves the cleavage of 2 or more benzene rings by monooxygenases like enzymes (Kweon et al., 2011; Sowada et al., 2014). In this study we identified two strains harboring in the plasmids to the genes pobA (H23) and fabHB (H38), enconding for the enzymes 4-hydroxybenzoate 3-monooxygenase and the ketoacyl-ACP synthase III, respectively.

In the real time PCR analysis, we observed the overexpression of the genes pobA and fabHB after $3 \mathrm{~h}$ of exposure to the $\mathrm{BaP}$ although it was not the case for the gene catE. The gene pobA that codes for the 4hydroxybenzoate 3-monooxygenase was 7.4-fold higher than the control, which indicates that the activity of this gene continues to occur until $3 \mathrm{~h}$ later to the exposure. In the strain $N$. pentaromativorans US6-1, the overexpression of the gene $H B M O$ that codes for the enzyme 4-hydroxybenzoate 3-monooxygenase was 6-fold higher than the control after $12 \mathrm{~h}$ of exposure to $\mathrm{BaP}$ (Lyu et al., 2014). The comparison of these results suggests that B. licheniformis M2-7, under the culture conditions that we used, overexpresses the protein 4hydroxybenzoate 3-monooxygenase in the earliest stages of the cellular growth in the presence of $\mathrm{BaP}$. The overexpression of the gene $\mathrm{fabHB}$ that codes for the enzyme ketoacyl-ACP synthase III after $3 \mathrm{~h}$ of incubation with $\mathrm{BaP}$, suggests that this gene also participates in the metabolism of PAHs. Although it has not yet been described in the genus Bacillus, it is proposed that under aerobic conditions and in the $\beta$-ketoadipate pathway, is where the gene $f a b H B$ participates. Finally, we quantified the expression of the gene $c a t E$, which we consider to be a control gene involved in the biodegradation of benzoapyrene, that codes for the enzyme catechol 2,3 dioxygenase, finding a basal expression during the exposure to $\mathrm{BaP}$, however in previous analysis the activity of the enzyme from $B$. licheniformis M2-7 was determined, finding $0.33 \mathrm{U} / \mathrm{mg}$ of protein after $3 \mathrm{~h}$ of incubation with BaP (Guevara-Luna et al. 2017, under review). This suggests that the expression of the gene catE occurs in earlier growth stages (within the first $3 \mathrm{~h}$ ) in the strain M2-7. Many authors have proposed a several bacteria as being able to use BaP, for example Mycobacterium sp. RGJII-135 degrades $40 \%$ of BaP after 32 days of incubation and supplemented with different carbon sources; M. vanbaalenii PYR-1, transforms BaP after $96 \mathrm{~h}$ of incubation; and Burkholderia cepacia degrades 20-30\% of BaP after 63 days of incubation (Juhasz et al., 1986; Schneider et al., 1996; Juhasz et al., 1997; Moody et al., 2004). Other reports have used consortia as the one formed by Ochrobactrum sp., Stenotrophomonas maltophilia and Pseudomonas fluorescens that was able to degrade $44.07 \%$ of $10 \mathrm{ppm}$ of $\mathrm{BaP}$ after 14 days of incubation (Luo et al., 2009). These results indicate that the degradation metabolism of $\mathrm{BaP}$ is complicated, additionally it is very slow, which makes it difficult to use these microorganisms in bioremediation. However, our system strongly suggests that it can metabolize the BaP within a period of $3 \mathrm{~h}$ under the tested conditions. With the last in mind we propose B. licheniformis M2-7 as an excellent alternative for application in bioremediation.

\section{Proposal of the degradation pathway of the $\mathrm{BaP}$ in $\mathrm{B}$. licheniformis M2-7}

According to the results reported recently by our group (Guevara-Luna et al., 2017, under review), and together with the identification and the expression analysis of the genes $p o b A$ and $f a b H B$, we suggest a transformation pathway for the $\mathrm{BaP}$ in $B$. licheniformis strain $\mathrm{M} 2-7$. The reactions would start with the incorporation of 
molecular oxygen on the carbons 9 and 10 from BaP through the enzyme catechol 2, 3-dioxygenase, generating the benzo[a]pyrene cis-9,10-dihydrodiol (Guevara-Luna et al., 2017, under review), this last metabolite undergoes another dioxygenation through the catechol 2,3-dioxygenase producing cis-4-(hydroxy-pyrene-8-yl)2-oxobut-3-enoic acid via meta (Cerniglia, 1992; Schneider et al., 1996). This is followed by the formation of 7,8-pyrene-dihydro-7-carboxylic acid (Schneider et al., 1996), through the high molecular weight PAHs degradation path described by Mahaffey et al., (1988), which involves a several enzymes and intermediaries metabolites.

Based on the results of the expression analysis of the genes pobA and $f a b H B$, coding for the enzymes 4hydroxybenzoate 3-monooxygenase and the ketoacyl-ACP synthase III, respectively. It is suggested that the second stage of degradation is similar to the one proposed in $M$. vanbaalenii PYR-1 for the degradation of pyrene (Heitkamp et al., 1988; Khan et al., 2001; Kim et al., 2005; Stingley et al., 2004a; Stingley et al., 2004b) and starts with the metabolism of the 7,8-pyrene-dihydro-7-carboxylic acid, through the oxygenation of the carbons 4 and 5 (K region) (Heitkamp et al., 1988), that we suggests it is carried out by the 4-hydroxybenzoate 3-monooxygenase (gene that was 7.4-fold higher than the control, Figure 2C). The subsequent formation of secondary metabolites that involve dioxygenation enzymatic reactions, results in the production of phthalic acid esters (Heitkamp et al., 1988; Kim et al., 2005; Stingley et al., 2004b; Guevara-Luna et al., 2017, under review). Although it has not been yet described in the genus Bacillus, it is believed that the gene fabHB, coding for the ketoacyl-ACP synthase III, participates under the $\beta$-ketoadipate pathway and in aerobic conditions (the gene showed an overexpression of 2.5 times more than the control, Figure $2 \mathrm{~B}$ ). Finally, under the $\beta$-ketoadipate pathway there is protocatechuate being generated from the phthalate (phthalic acid), until intermediaries that can enter the tricarboxylic acid cycle (Ornston and Stanier, 1966; Iwagami et al., 2000; Sim et al., 2013).

\section{CONCLUSION}

In conclusion, this investigation showed that during the growth of Bacillus licheniformis M2-7 under induction with $\mathrm{BaP}$, the bacterium overexpresses the genes $p o b A$ and $\mathrm{fabHB}$, encoding the enzymes 4-hydroxybenzoate 3monooxygenase and the ketoacyl-ACP synthase III, respectively. Moreover, previous analysis discovered the intermediary metabolite phthalic acid and the activity of the enzyme $\mathrm{C} 23 \mathrm{O}$ was measured. In the same way, it was also shown that in the B. licheniformis strain M2-7, this effect is achieved in a very short period after induction with $\mathrm{BaP}$, making this bacterium and excellent alternative to apply in bioremediation. This investigation provides a basis for understanding the $\mathrm{BaP}$ metabolism in this bacterium, however, characterization of catabolic genes and identification of key enzymes will enable the full characterization in $B$. licheniformis M2-7.

\section{ACKNOWLEDGEMENTS}

Augusto Rojas Aparicio thanks Consejo Nacional de Ciencia y Tecnología for M.Sc. scholarship (597152). We are grateful to Travis Ashworth for the critical discussions and language revision of this work.

\section{REFERENCES}

Abraham WR, Meyer H and Yakimov M (1998). Novel glycine containing glucolipids from the alkane using bacterium Alcanivorax borkumensis. Biochim. Biophys. Acta. 1393: 57-62. https://doi.org/10.1016/s0005-2760(98)00058-7

Banach-Szott M, Debska B, Wisniewska A and Pakula J (2015). Changes in the contents of selected polycyclic aromatic hydrocarbons in soils of various types. Environ Sci Pollut Res Int. 22 (7): 5059-5069. https://doi.org/10.1007/s11356-014-3901-9

Biemans-Oldehinkel E, Doeven MK and Poolman B (2006). ABC transporter architecture and regulatory roles of accessory domains. FEBS Lett. 580 (4): 1023-1035. https://doi.org/10.1016/j.febslet.2005.11.079

Bradford, MM (1976). A rapid and sensitive method for the quantitation of microgram quantities of protein utilizing the principle of proteindye binding. Anal Biochem. 7: 248-254. https://doi.org/10.1006/abio.1976.9999 
Cerniglia CG, (1992). Biodegradation of polycyclic aromatic hydrocarbons. Biodegradation. 3: 351-368. https://doi.org/10.5353/th_b4596106

Dean M, Rzhetsky A and Allikmets R (2001). The human ATP-binding cassette (ABC) transporter superfamily. Genome Res. 11(7): $1156-$ 1166. https://doi.org/10.1101/gr.gr-1649r

Harvey RA (1996). Mechanisms of carcinogenesis of polycyclic aromatic hydrocarbons. Polycycl Aromat Compd. 9 (4): 1-23. https://doi.org/10.1080/10406639608031196

Heitkamp MA, Freeman JP, Miller DW and Cerniglia CE (1988). Pyrene degradation by a Mycobacterium sp.: identification of ring oxidation and ring fission products. Appl. Environ. Microbiol. 54: 2556-2565.

Holden PA, LaMontagne MG, Bruce AK, Miller WG, et al. (2002). Assessing the Role of Pseudomonas aeruginosa Surface-Active Gene Expression in Hexadecane Biodegradation in Sand. Appl. Environ. Microbiol. 68(5): 2509-2518. https://doi.org/10.1128/aem.68.5.25092518.2002

IARC (International Agency for Research in Cancer) (1983). Monograph on the evaluation of carcinogenic risks to humans, vol. 32. International Agency for Research in Cancer, Lyon, France.

Johnson DR, Coronado E, Moreno-Forero SK, Heipieper HJ, et al. (2011). Transcriptome and membrane fatty acid analyses reveal different strategies for responding to permeating and non-permeating solutes in the bacterium Sphingomonas wittichii. BMC Microbiol. 11(1): 14711480. https://doi.org/10.1186/1471-2180-11-250

Juhasz A, Britz ML and Stanley GA (1986). Degradation of high molecular weight polycyclic aromatic hydrocarbons by Burkholderia cepacia. Biotechnol. Lett. 18(5): 577-582. https://doi.org/10.1007/bf00140206

Juhasz A, Britz M and Stanley G (1997). Degradation of fluoranthene, pyrene, benzo[a]anthracene and dibenzo[a,h]anthracene by Burkholderia cepacia. J. Appl. Microbiol, 83: 189-198.

Khan AA, Wang R, Cao W, Doerge DR, et al. (2001). Molecular cloning, nucleotide sequence, and expression of genes encoding a polycyclic aromatic ring dioxygenase from Mycobacterium sp. strain PYR-1. Appl. Environ. Microbiol. 67(8): 3577-3585. https://doi.org/10.1128/aem.67.8.3577-3585.2001

Kanaly RA and Harayama S (2000). Biodegradation of high-molecularweight polycyclic aromatic hydrocarbons by bacteria. J. Bacteriol. 182 (8): 2059-2067. https://doi.org/10.1128/jb.182.8.2059-2067.2000

Kanaly RA and Harayama S (2010). Advances in the field of high-molecular-weight polycyclic aromatic hydrocarbon biodegradation by bacteria. Microb Biotechnol. 3 (2): 136-164. https://doi.org/10.1111/j.1751-7915.2009.00130.x

Kato S and Watanabe K (2009). Analysis of Gene Transcripts in a Crude Oil-Degrading Marine Microbial Community. Biosci Biotechnol Biochem. 73 (7): 1665-1668. https://doi.org/10.1271/bbb.90072

Kim YH, Freeman JP, Moody JD, Engesser KH, et al. (2005). Effects of pH on the degradation of phenanthrene and pyrene by Mycobacterium vanbaalenii PYR-1. Appl. Microbiol. Biotechnol. 67(2): 275-285. https://doi.org/10.1007/s00253-004-1796-y

Kim SJ, Kweon O, Jones RC, Freeman JP, et al. (2007). Complete and integrated pyrene degradation pathway in Mycobacterium vanbaalenii PYR-1 based on systems biology. J. Bacteriol. 189(2): 464-472. https://doi.org/10.1128/jb.01310-06

Kim SJ, Kweon O, Jones RC, Edmondson RD, et al. (2008). Genomic analysis of polycyclic aromatic hydrocarbon degradation in Mycobacterium vanbaalenii PYR-1. Biodegradation. 19: 859-881. https://doi.org/10.1007/s10532-008-9189-z

Kim H, Yim B, Kim J, Kim H, et al. (2017). Molecular characterization of ABC transporters in marine ciliate, Euplotes crassus: Identification and response to cadmium and benzo[a]pyrene. Mar Pollut Bull. 124(2): $725-735$. https://doi.org/10.1016/j.marpolbul.2017.01.046

Kweon O, Kim SJ, Holland RD, Chen H, et al. (2011). Polycyclic aromatic hydrocarbon metabolic network in Mycobacterium vanbaalenii PYR-1. J Bacteriol. 193: 4326-4337.

Luo YR, Tian Y, Huang X, Yan CL, et al. (2009). Analysis of community structure of a microbial consortium capable of degrading benzo(a)pyrene by DGGE. Mar Pollut Bull. 58(8): 1159-1163. https://doi.org/10.1016/j.marpolbul.2009.03.024

Lyu Y, Zheng W, Zheng T and Tian Y (2014). Biodegradation of polycyclic aromatic hydrocarbons by Novosphingobium pentaromativorans US6-1. PLoS ONE, 9: 1-7. https://doi.org/10.1371/journal.pone.0101438 
Mahaffey WR, Gibson DT and Cerniglia CE (1988). Bacterial oxidation of chemical carcinogens: formation of polycyclic aromatic acids for benz[a]anthracene. Appl. Environ. Microbiol. 54: 2415-2423.

Moody JD, Freeman JP, Fu PP and Cerniglia, CE (2004). Degradation of benzo[a]pyrene by Mycobacterium vanbaalenii PYR-1. Appl Environ Microbiol. 70 (1): 340-345. https://doi.org/10.1128/aem.70.1.340-345.2004

Oldham ML, Davidson AL and Chen J (2008). Structural insights into ABC transporter mechanism. Curr. Opin. Struct. Biol. 18 (6): $726-$ 733. https://doi.org/10.1016/j.sbi.2008.09.007

Ornston LN and Stanier RY (1966). The conversion of catechol and protocatechuate to $\beta$-ketoadipate by Pseudomonas putida. J. Biol. Chem. 241: 3776-3786.

Rooney SA (1979). Biosynthesis of lung surfactant during fetal and early postnatal development. Trends Biochem Sci. 4 (8): 189-191. https://doi.org/10.1016/0968-0004(79)90423-7

Iwagami SG, Yang K and Davies J (2000). Characterization of the protocatechuic acid catabolic gene cluster from Streptomyces sp. Strain 2065. Appl Environ Microbiol, 66 (4): 1499-1508. https://doi.org/10.1128/aem.66.4.1499-1508.2000

Schneider J, Grosser R, Jayasimhulu K, Xue W et al. (1996). Degradation of pyrene, benz[a]anthracene, and benzo[a]pyrene by Mycobacterium sp. strain RJGII-135, isolated from a former coal gasification site. Appl. Environ. Microbiol. 62: 13-19.

Sim HW, Jung MJ and Cho YK (2013). Purification and characterization of protocachuate 3,4-dioxygenase from Pseudomonas pseudoalcaligenes KF707. J Korean Soc Appl Bi. 56(4): 401-408. https://doi.org/10.1007/s13765-013-3080-2

Sowada J, Schmalenberger A, Ebner I, Luch A, et al. (2014). Degradation of benzo[a]pyrene by bacterial isolates from human skin. FEMS Microbiol Ecol, 88: 129-139. https://doi.org/10.1111/1574-6941.12276

Stingley RL, Brezna B, Khan AA and Cerniglia CE (2004a). Novel organization of genes in a phthalate degradation operon of Mycobacterium vanbaalenii PYR-1. Microbiology. 150 (11): 3749-3761. https://doi.org/10.1099/mic.0.27263-0

Stingley RL, Khan AA and Cerniglia CE (2004b). Molecular characterization of a phenanthrene degradation pathway in Mycobacterium vanbaalenii PYR-1. Biochem. Biophys. Res. Commun. 322(1): 133-146. https://doi.org/10.1016/j.bbrc.2004.07.089

Vázquez-Gómez G, Rubio-Lightbourn J and Espinosa-Aguirre JJ (2016). Mecanismos de acción del receptor de hidrocarburos de arilos en el metabolismo del benzopireno y el desarrollo de tumores. Revista Especializada en Ciencias Químico-Biológicas, 19 (1): 54-67. https://doi.org/10.1016/j.recqb.2016.02.006

Zaccai NR, Carter LG, Berrow NS, Sainsbury S, et al. (2008). Crystal structure of a 3-oxoacyl-(acyl carrier protein) reductase (BA3989) from Bacillus anthracis at 2.4- $\mathrm{A}^{\circ}$ resolution. Proteins. 70: 562-567. https://doi.org/10.2210/pdb2uvd/pdb

Zeinali M, Vossoughi M and Ardestani SK (2008). Naphthalene metabolism in Nocardia otitidiscaviarum strain TSH1, a moderately thermophilic microorganism. Chemosphere. 72(6): 905-909. https://doi.org/10.1016/j.chemosphere.2008.03.038

\section{Appendix}

\section{Supplementary material}

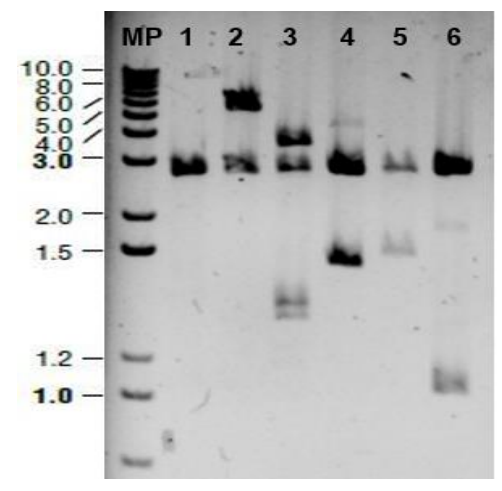

Figure S1. Analysis of the inserts cloned in pUC18. 
Lane MP: molecular ladder 1Kb; Lane 1: linear pUC18 digested with HindIII; lane 2: plasmid from strain B24 digested with BamHI; lane 3: plasmid from the strain H23 digested with HindIII; lane 4: plasmid from the strain H38 digested with HindIII; lane 5: plasmid from the plasmid in the strain H66 digested with HindIII; and lane 6: plasmid with the strain $\mathrm{H} 218$ digested with HindIII. $1 \%$ agarose gel at 120 volts. 